\title{
Total IgA and IgG levels in goats fed diets including greenhouse wastes
}

\author{
M. Romero-Huelva, L. Abecia, D. R. Yáñez-Ruiz and E. Molina-Alcaide \\ Estación Experimental del Zaidín (CSIC), Profesor Albareda, 1, Granada, Spain
}

The aim of this work was to study the inclusion of unconventional feedstuffs such as greenhouse horticulture wastes (fruits of tomato and cucumber), in ruminants diet as an alternative to concentrates. Plant secondary compounds which might be present in greenhouse wastes could result in methane reduction ${ }^{(1,2)}$. Therefore, the inhibition of methane production is associated to changes in the ruminal microbiota, which could modify the host immunity.

Four adult dry non-pregnant rumen-fistulated Murciano-Granadina goats were used in a $4 \times 4$ Latin square experimental design. Four 39-d trials were carried out to study four experimental diets: alfalfa hay plus concentrate in a $1: 1$ ratio (diet AC) or $1: 0.5$ plus feed blocks including wastes of tomato (diet ACT) and cucumber (diet ACC) fruits or barley grain (diet ACB). Feed blocks were supplied ad libitum, resulting in average intakes of 203 (SE 72.9), 179 (SE 39.7) and 144 (SE 68.1) g of fresh matter/animal/d, respectively, for feed blocks based on tomato, cucumber and barley, but total DM intake was not modified $(P=0.605)$ by diet. Average goat's body weight (BW) was not affected $(P=0.310)$ by diet (Table 1$)$. From day 36 to 39 of each trial animals were moved to a set of four open circuit respiration chambers for methane emissions measurement. To assess the effect on the immune system total $\operatorname{IgA}$ and $\operatorname{IgG}$ concentrations were measured in plasma by ELISA.

The replacement of $50 \%$ of concentrate with feed blocks including tomato or cucumber wastes did not have any significant effect either in total $\operatorname{IgA}(P=0.906)$ or $\operatorname{IgG}(P=0.983)$ antibody concentrations in plasma. Diet including tomato-based feed blocks decreased $(P<0.001)$ methane emission by $33 \%$ compared to the other experimental diets (Figure).

Table. Average body weight $(\mathrm{kg})$, total DM intake $(\mathrm{g})$ and total $\mathrm{IgA}(\mathrm{ng} / \mathrm{mL})$ and $\mathrm{IgG}(\mathrm{mg} / \mathrm{mL})$ antibody concentrations in plasma of goats fed the experimental diets $(n=4)$

\begin{tabular}{|c|c|c|c|c|c|c|}
\hline & \multicolumn{4}{|c|}{ Diet } & \multirow[b]{2}{*}{ SEM } & \multirow[b]{2}{*}{$P$-value } \\
\hline & $\overline{\mathrm{AC}}$ & ACT & $\mathrm{ACC}$ & $\overline{\mathrm{ACB}}$ & & \\
\hline $\mathrm{BW}$ & 31.8 & 32.7 & 31.6 & 32.4 & 3.05 & 0.310 \\
\hline DMI & 639 & 651 & 639 & 586 & 31.2 & 0.605 \\
\hline $\operatorname{IgA}$ & 15.5 & 15.9 & 15.4 & 16.8 & 0.371 & 0.906 \\
\hline IgG & 8.87 & 9.27 & 8.95 & 8.79 & 0.191 & 0.983 \\
\hline
\end{tabular}

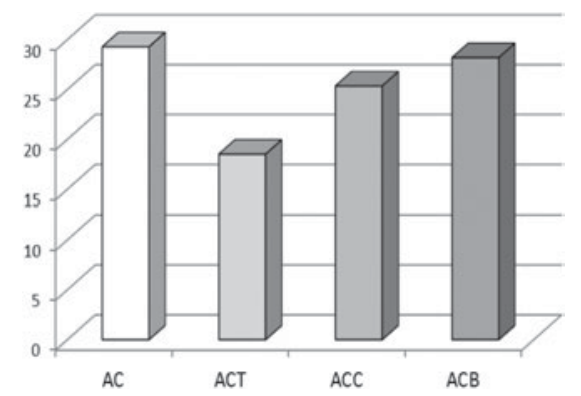

Figure. Methane emissions (L/kg DMI) of goats fed the experimental diets.

Our study suggests that the inclusion of greenhouse wastes in goat's diet did not promote changes on the Ig levels in plasma although diets including tomato feed blocks showed a strong antimethanogenic effect.

1. Martín C, Morgavi D \& Doreau M. (2010) Animal 4, 351-365.

2. Newbold CJ, McIntosh FM, Williams P et al. (2004) Anim Feed Sci Tech 114, 105-112. 